\title{
The ecology of ecology
}

"Ecology has become a social movement as well as a branch of biology". Philip Lowe of University College, London, and Michael Worboys of Sheffield City Polvtechnic give their view on the role of science in the environmental movement

ENVIRONMENTAL concern, and with it the apparent immediacy of the ecological crisis, has of late receded. A downturn in the business cycle has sets its own limits to growth, and apocryphal warnings of the decline of Western capitalist democracies have superseded the environmentalists' warnings of natural decay. But many environmental problems remain, and one enduring feature of many of these is their implication of modern science, both as cause and as solution.

From the anxiety over radioactive fall-out and pesticides, through to current worries about fluorocarbons, nuclear power and hazards of the workplace, science has often been cast as the villain of the piece. Yet scientists have also been in the forefront in alerting society about these problems and in campaigning for action. Moreover, a leading role for science has been proposed in evaluating risks from pollution, in developing new resources and in the general formulation of solutions and strategies in response to environmental problems.

This ambivalence with regard to science-which is, incidentally, very common where science impinges upon social issues-creates many difficulties. For example, different scientists may regard the same "problem" very differently. Whose assessment or warning do we believe? To solve environmental problems, do we need more science, less science or different science? To which group of scientists, if any, do we turn for solutions? One common response to questions of this sort has been to look to ecology and ecologists as sources of "wisdom" and "healing". The received notion that ecology is about wholeness and the natural has left it seemingly untainted by the reductionist and industrial associations of most modern science.

Indeed, its marginality to mainstream science, of which ecologists have long complained, now proves to be an asset in a period when science generally is being questioned and attacked. Most environmentalists and environmental pressure groups have fallen in behind the banner of Ecology. They have used ecological information vicariously and promoted the adoption of ecological values, giving rise to a whole new genre of social polemic best described as popular ecology. In short, ecology has become a social movement as well as a branch of biology, and it is the connection between these two aspects of ecology that needs to be explored.

\section{Is politics redundant?}

The literature of the contemporary environmental movement and popular ecology is characterised by a general rejection of conflict, especially political conflict: the lesson of ecology in its broadest sense is supposedly harmony, balance and symbiosis. As in technocracy, where traditional politics is deemed redundant through the overriding and deterministic effects of man's technological situation, so in popular ecology politics is declared equally redundant because of the imperatives of man's ecological predicament. Compelling physical and natural constraints supersede and replace moral, social and political considerations.

In Britain, the establishment of an Ecology Party indicates the presumption that environmental issues transcend orthodox political alignments. Formed in 1973 as a direct consequence of the appeal in the Blueprint for Survival for "a national movement to act at national level, and if need be to assume political status and contest the next general election", it was known initially as the People Party-its subsequent change of name illustrating nicely how ecology has come to be seen as bigger than all of us. The electoral ambitions of the Ecology Party, its commitment to come to power by democratic means and work within the framework of a mixed capitalist economy and a parliamentary democracy, are somewhat at odds with its very radical manifesto proposals for de-growth, decentralisation and population control "to provide a working basis for ecological government". However, recent correspondence in their broadsheet, Alliance, has argued that it may in fact be essential for government, composed of an aware elite-the writer used the Spaceship Captain analogy"to introduce ecology without taking the people into its confidence".

But most environmentalists would not completely abolish politics. Some view politics as the refined tool of environmental management, enabling fine and delicate control of human well-being within the greater and larger purposes of the biosphere. The implication is that, as well as transcending political differences, environmental problems are also non-political in the sense that their solutions are management or technical issues. Hence, politics should no longer be about power, its use and distribution, but, instead, about the forms or techniques of government most appropriate to cope with urgent environmental problems.

\section{Conventional response}

The conventional response of the scientific establishment to environmental problems was expressed by the Council for Scientific Policy in 1972, when it urged that "more science will be needed, not less, to provide remedies and to enable society to take precautions against pollution", and called for the "closer integration of science into social policies". Thus, more "scientific" planning, monitoring and management are advocated, in such forms as technology assessment, environmental impact analysis, quantitative environmental forecasting and ecological evaluationactivities viewed by their practitioners as so many exercises in applied rationality, but criticised by others for clothing implicit political assumptions and implications in a pseudo-scientific mystique of "objective" knowledge and "rational" techniques. What is clear is that their practice seems to be based on the assumption of the availability of consensually defined social goals which, if absent, can be summonsed by the persuasive presentation of the facts of the matter. 


\section{Ecological coalition}

Conservation, when treated in these terms, appears to be an unadulterated good thing; equated with applied ecology and with its own quantitative techniques, it seems beyond the realm of politics. The supposed political consensus surrounding the practice of conservation in Britain, however, can also be seen to be the operation of a coalition of powerful rural vested interests, whose use of ecological rhetoric has enjoyed the active support or acquiescence of professional ecologists. In fact, popular ecology has long been very closely linked with the interests and ambitions of professional ecologists.

The institutionalisation of a scientific discipline such as ecology is generally accompanied by the competitive development of a disciplinary ideology which publicises the putative social utility and world-view of the discipline and plays an essential role in the establishment of cohesion and a sense of collective identity amongst its practitioners. In Britain, the emergence of ecology as a distinct discipline dates from the turn of the century. Government recognition of its potential utility came in 1949 with the establishment of the Nature Conservancy as both a research council for ecology and an agency for the formation and management of nature reserves.

Initially, the Nature Conservancy commanded a very much smaller share of resources than the other research councils, and ecology, with its amateur connotations of natural history, had a low status in the scientific community. But the Conservancy proved very successful in lobbying government and popularising ecology, and took the leading role in forging various groups into an effective and dynamic environmental lobby. In the late 1960 s members of the Conservancy played a crucial part in popularising the existence of an environmental crisis and figured prominently in the institutional developments that were the outcome of the resulting public and governmental concern. Hence a strong element in ecological propaganda is a direct product of competition within science.

\section{Whose preserve?}

The further suggestion that the environmental crisis reflected the preeminence of the physical sciences over the environmental sciences has also had considerable currency. It is indeed true that many science-related activities associated with both the generation and control of environmental problems, have been the preserve of chemists and engineers, largely to the exclusion of biologists. Thus, much pollution, such as that due to pesticides, detergents and nuclear radiation, has been seen to be consequent upon faulty and diminutive knowledge of environmental biology as compared with, say, physics and chemistry-indicating to some the need for a greater share of resources to be devoted to research and training in the environmental sciences.

To many others, however, this analysis, in confining itself to relative deficiencies within science, does not go far enough and fails to recognise the economic and social basis of the organisation of science. The preponderance of the chemical control of pests over their biological control, for example, and the resultant pollution and development of pest resistance, may be less a function of the power of chemists over biologists than of the power of the chemical industry within society. Professional competition and interfactional disputes within science often need to be understood in terms of the relationship between scientific disciplines and elites and powerful interests external to science.

\section{Beyond tactical responses}

The plausibility of ecologists has been of crucial importance, and was directly involved in their popularisation of the environmental crisis, just as their professional interests are deeply enmeshed in "technical" solutions to environmental problems. In some instances, however, the appeal to ecology has gone beyond the search for tactical responses to particular problems, towards the claim that ecology can contribute to a radical re-ordering of human purposes and a re-orienting of society away from environmental disaster. The findings, concepts and approach of ecology have proved a rich source of ideas and analogies in the construction of environmentally sound social programmes-niche theory, the ecosystem concept, energy flow, materials recycling, limits of tolerance and succession have been deployed in many and varied contexts.

Beyond this have come calls for ecological ideals, an ecological ethic, an ecological morality, ecological values and ecological determinism. Certainly, the synthetic nature of ecology and its claims to transcend the narrowness of other disciplines have always been a source of its popular support. But, in this case, science appears to be adopting a leading role in society as a value-affirming, goal-setting and consensus-generating institution. At a time of change and dissent from established values, when it is generally accepted that traditional institutions have lost much of their authority, science, albeit reunified and chastened by the example of ecology, is turned to by those who value order and stability as the one authoritative voice.

\section{Science assailed}

Such appeals to science, however, come at a time when its own moral influence has also been assailed, by the attacks of what many identify as an anti-science movement. The response of critics like Roszak to the social problems of modern science has been to reject science-the objective, rational and calculating consciousness-in favour of a more subjective, intuitive and feeling type of knowledge. For Roszak, the discipline of ecology, and not high energy physics, should be the model science-a view shared by influential and respected proponents of ecology such as Max Nicholson and Barry Commoner.

The separate debate over social responsibility in science has raised other questions about the direction and control of science. The self-doubt that has been generated has prompted some leading scientists to demand greater solidarity and less dissent within the scientific community so as to render it less vulnerable to external attack and to preserve its authority in society. Indeed, internal fragmentation has been identified as one cause of the inability of science to respond effectively to environmental problems, and calls for a "unified science", based on ecology and the related general systems theory, predict the consequent restoration of the weakened position of science in society. The holistic image of ecology, its promise of making whole that which was fragmented, and its widespread popular support, might help revive the moral influence of science, and regenerate consensus both within and outside of science.

\section{Crisis highlighted}

The environmental crisus thus highlights a crisis of confidence within science and a crisis of science's authority in society. Mary Douglas, in her essay "Environments at Risk" (Times Literary Supplement, October 30, 1970), has supported this view by drawing attention to the problems of credibility that scientists face in warning society of possible environmental dangers. Indeed, the environmental movement has been interpreted by Michael King (Technology and Society, 8,$1 ; 1973$ ) as a bid by certain scientists to relocate and extend the basis of scientific authority. Science as a mere source of useful knowledge confers upon scientists the very limited and fragile power of technicians, but the ecologists' claim to appreciate the wisdom of Nature, as well as the orthodox scientists' knowledge of natural laws, might legitimate a continuous and central involvement in the formulation of political purposes and values. 